\title{
COMPARISON OF IMAGE ENHANCEMENT METHODS FOR CHROMOSOME KARYOTYPE IMAGE ENHANCEMENT
}

\author{
Dewa Made Sri Arsa', Grafika Jati' ${ }^{1}$, Agung Santoso ${ }^{2}$, Rafli Filano² ${ }^{2}$, Nurul Hanifah' ${ }^{2}$, and \\ Muhammad Febrian Rachmadi ${ }^{3}$ \\ ${ }^{1}$ Faculty of Computer Science, Universitas Indonesia, Kampus UI, Depok, 16424, Indonesia \\ ${ }^{2}$ Study Program of Biomedic Technology, Magister Program, Universitas Indonesia \\ ${ }^{3}$ School of Informatics, The University of Edinburgh, 11 Crichton Street, Edinburgh EH8 9LE, United \\ Kingdom \\ E-mail: dewa.made51@ui.ac.id¹, agung_i_s@yahoo.com²,s1467961@sms.ed.ac.uk ${ }^{3}$
}

\begin{abstract}
The chromosome is a set of DNA structure that carry information about our life. The information can be obtained through Karyotyping. The process requires a clear image so the chromosome can be evaluate well. Preprocessing have to be done on chromosome images that is image enhancement. The process starts with image background removing. The image will be cleaned background color. The next step is image enhancement. This paper compares several methods for image enhancement. We evaluate some method in image enhancement like Histogram Equalization (HE), Contrast-limiting Adaptive Histogram Equalization (CLAHE), Histogram Equalization with 3D Block Matching (HE+BM3D), and basic image enhancement, unsharp masking. We examine and discuss the best method for enhancing chromosome image. Therefore, to evaluate the methods, the original image was manipulated by the addition of some noise and blur. Peak Signal-to-noise Ratio (PSNR) and Structural Similarity Index (SSIM) are used to examine method performance. The output of enhancement method will be compared with result of Professional software for karyotyping analysis named Ikaros MetasystemT M . Based on experimental results, HE+BM3D method gets a stable result on both scenario noised and blur image.
\end{abstract}

Keywords: Chromosome, DNA, Image Enhancement, MetaSystem Ikaros, Image Processing

\begin{abstract}
Abstrak
Kromosom adalah kumpulan struktur DNA yang membawa informasi makhluk hidup. Informasi yang dapat diperoleh dengan proses Kariotyping. Proses ini membutuhkan citra yang jelas sehingga kromosom dapat dievaluasi dengan baik. Preprocessing harus dilakukan pada citra kromosom melalui penajaman citra. Proses ini dimulai dengan menghapus latar belakang citra. Langkah berikutnya ialah penajaman citra menggunakan metode image enhancement. Makalah ini membandingkan beberapa metode untuk peningkatan citra. Kami mengevaluasi beberapa metode dalam peningkatan gambar seperti Histogram Equalization (HE), Contrast-limiting Adaptive Histogram Equalization (CLAHE), Histogram Equalization with 3D Block Matching (HE+BM3D), dan unsharp masking. Penulis mengevaluasi dan membahas metode terbaik untuk meningkatkan citra kromosom. Oleh karena itu, untuk mengevaluasi metode, gambar asli dimanipulasi dengan penambahan beberapa kebisingan dan blur. Peak Signal-to-noise Ratio (PSNR) and Structural Similarity Index (SSIM) digunakan untuk mengukur kinerja metode. Hasil penajaman dari metode-metode yang dievaluasi akan dibandingkan dengan hasil software profesional untuk analisis kariotipe bernama Ikaros Metasystem T M . Berdasarkan eksperimen diperoleh hasil bahwa HE + BM3D merupakan metode yang paling stabil pada kedua skenario baik citra mengandung noise maupun citra yang kabur.
\end{abstract}

Kata Kunci: Kromosom, DNA, Peningkata Citra, Sistem Meta Ikaros, Pengolahan Citra

\section{Introduction}

Chromosomes can not be observed with naked eyes. The existence of chromosomes is not known until the development of microscopes which can magnify an object image up to 1000 times. Chromosomes are surrounded by a wall and a thick membrane that is called as the nucleus. It is transparent, but pale, so difficult to distinguish from the environment. Then chromosome is colored into purple, red, green using extract Gentiana flower. In 1888, a German cytological, W. Waldeyer bring out chromosome, which comes 
from the Greek word chroma is meaning color and some is meant body [1].

A chromosome is a collection of DNA arrangements that carry information of our life. The human gen coding only use (3\%) of the total DNA, then the rest of it is called as nonsense DNA. Gilbert in 2000 said that humans had 150,000 genes, But in 2001 Bork and Copley clarify that basa in the human genome is 39.114 genes (Celera) and 31.780 (The Public Sequence). And then in 2003, Pennisi informs that human genes was decreased again to 20,000. A single gene can produce hundreds of different proteins. These proteins can be grouped into 1,000 families based on their similarity. Therefore, at least 1,000 primary gene responsible for the protein $[1,2]$.

Chromosomes contain of information about human being. Chromosomes can be used to diagnose diseases and disorders suffered by the individual. Several diseases and disorders can be detected from the different chromosomes between normal and abnormal chromosomes. Some disorders are diagnosed based on the chromosome information like Down Syndrome, Patau Syndrome, Edward's Syndrome, Turner Syndrome, Klinefelter Syndrome, Cri-du-chat (cat's cry) syndrome, Prader-Willi Syndrome (PWS), Angelman Syndrome (AS) and so on.

The chromosomes information can be extract using a karyotype technique. Karyotype is started by isolated chromosome from cell then observed through a microscope and organized into somatic chromosomes 1 to 22 and one sex chromosome. We utilize microscope to produce chromosome image as primary diagnostic tool. Chromosome image analysis methodology is divided into two step pre- processing algorithm and classification or analysis. That process still be done manually. Pre-processing algorithm are perform bounding box each chromosome, textural correction, and geometric correction [3]. The textural correction is essential cause original image contain noises, blur, even distortion. They come from poor sample preparation, low contrast band patterns, digital quantization and imaging [4-7]. These noise and distortion cause the karyotyping and identification of chromosome become more difficult and inaccurate. Therefore, the image needs to improve the quality. Moreover, enhance image quality was produced by microscope still conduct manually. The result still depend on human who enhance the image. To solve this problem, computer processing and image processing algorithm are needed and open problem. Some methods were developed such as Histogram Equalization [8], Contrastlimiting Adaptive Histogram Equalization [9], Histogram Equalization with 3D Block Matching
(HE+BM3D) [10], and well-know unsharp masking [11]. This paper is going to evaluate the performance of image enhancement methods for chromo- some image analysis. We have to get best methods that obtain good result on both noised or blurred chromosome image. The appropriate methods will improve the image quality through image enhancement. So the abnormality of chromosome can be identified well [12].

This paper has been written in 7 sections. The first section is the introduction which is this section. The second section, which is the next section, is describing some related works for chromosome theory and previous researches which tried to improve image quality. The third section describing methods that we used in the experiment. Then, the fourth section showed our scenario of experiments. Section fifth showed experiment results. The sixth section is the discussion of the results of the experiment. The last section is the references.

\section{Methods}

\section{Chromosomes Theory}

The chromosomes can be analyzed microscopically. Karyotyping will identify individual Chomosome based on size and shape. In humans, there are 22 pairs of somatic chromosomes and one pair of sex chromosome. Each pair of chromosomes has various sizes and structure. In general, there are four types of structures of different chromosomes in humans, namely telocentric, acrocentric, metacentric and submetacentric. Photomicrograph metaphase Chomosomes of cells are arranged in homologous pairs from longest chromosomes until shortest Chomosomes. Then sex chromosome is grouped steparately (Figure 1) [2].

The structure and amount of chromosomes is not always normal and there is always the possibility of a chromosomal mutation that cause function of certain parts of the body became abnormal. Therefore, it is important to get the clear picture karyotype to identify an abnormality or disease. Many abnormalities that can viewed of chromosomal mutations, such as Down Syndrome where their aneuploidy trisomy of the 21st chromosome (Figure 4); Cri-du-chat syndrome, also known as 5p-syndrome that occurs deletion on chromosome 5 (Figure 5); and Philadelphia chromosome t $(9 ; 22)$ (Q34; Q11), namely the occurrence of chromosomal translocation, Nowell in 1960 found the tiny chromosomes unusual (Figure 6) see in leukocytes in patients with chronic myelogenous leukemia [12]. 


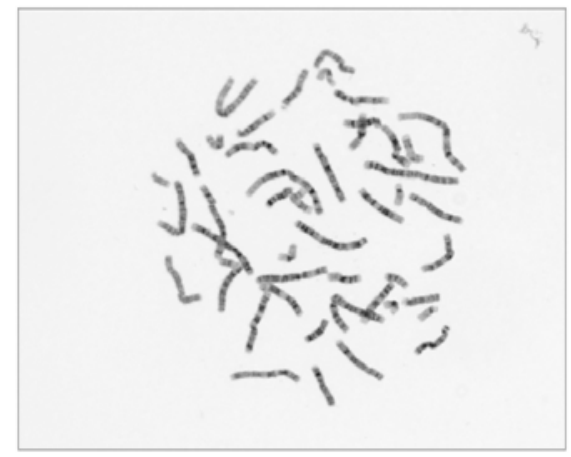

(a)

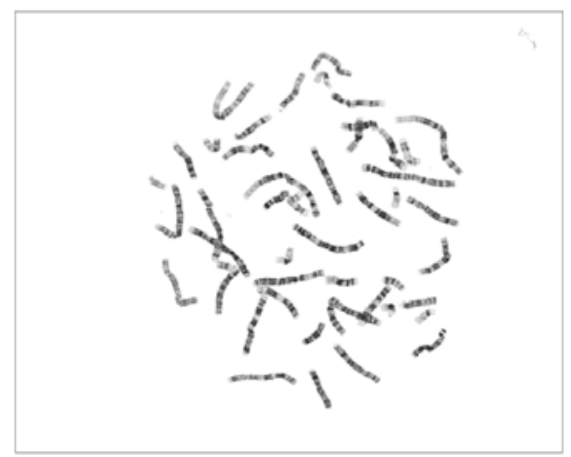

(b)

Figure 1. (a) Fetus Amnion chromosome (MetaSystem), (b) Enhanced image produced by MetaSystem

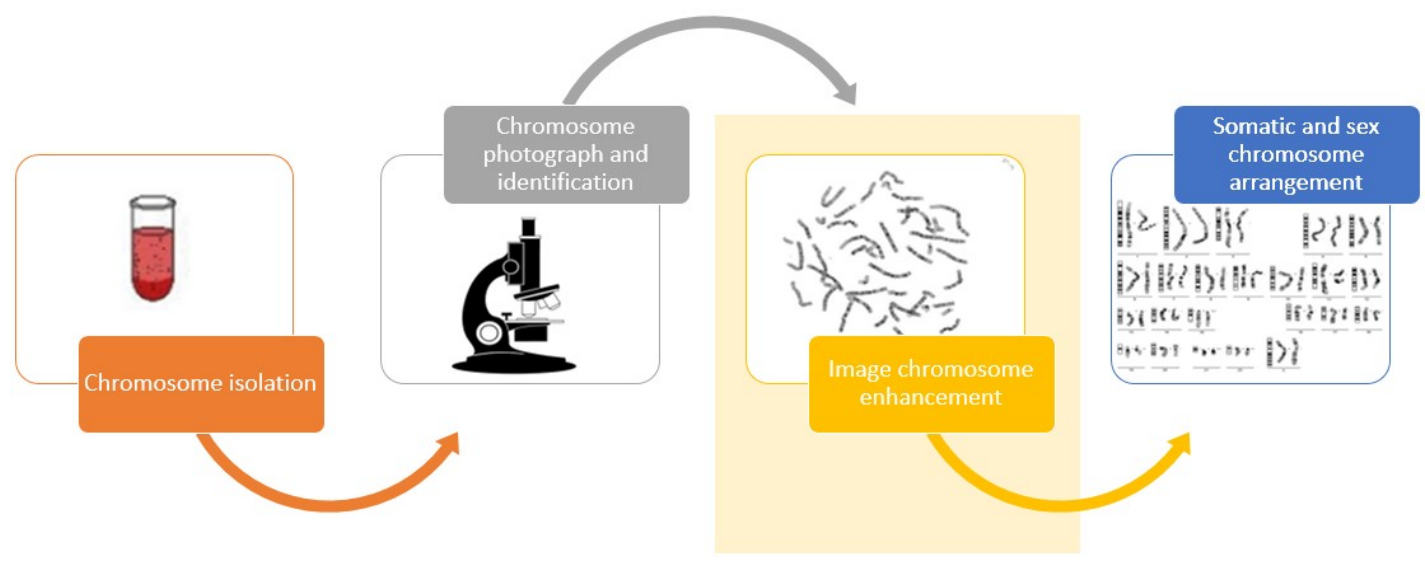

Figure 2. Research position

\section{Previous Works to Improved Quality Images}

Imaging has been progressing with the advancement of technology and science. The reason why the images can be digitized is to be converted into a computer can be stored in memory or other forms of storage media such as CD-ROM or hard disk. The digital image is a representation of a two-dimensional image as a finite set of digital values known as pixels or picture elements. Digitization procedure can be done through the scanner or video camera. After the image is digital, it can be done using digital image Frocessing by placing emphasis on two main tasks: improvement of pictorial information for the murposes of human interpretation and processing of image data for storage, representation, and transmitting the perception of independent machines. Digital image processing (Digital Image Processing) is a discipline that studies the techniques of image processing. Image is meant here is of still images (photos) and moving images (derived from the webcam). Meanwhile, here are intentions that digital image processing /image is done digitally using a computer $[13,14]$.

The purpose of digital image processing is to find the delegate intensity distribution of any image and transform 3D to 2D images that can be used for quantitative morphological descriptions and representations. Digital image processing often involved many procedures such as formatting and improve data, digital Increased to increase the enhanced visual interpretation, or automatic target classification and features hentirely by computer. There are several methods or different techniques of digital image processing procedures. As preprocessing, Image Enhancement, Image Transformation and Image Classification and Analysis are commons image processing functions provided in the image analysis. Preprocessing is often required before the primary analysis of data and information extraction. It is also need broadly classified as geometric or radiometric correction. Image enhancement invol- 


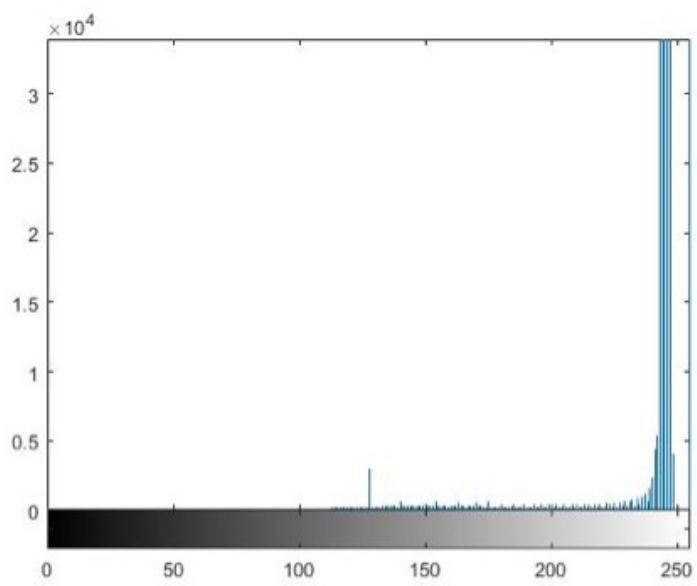

Figure 3. Histogram of chrommosome image before background was removed

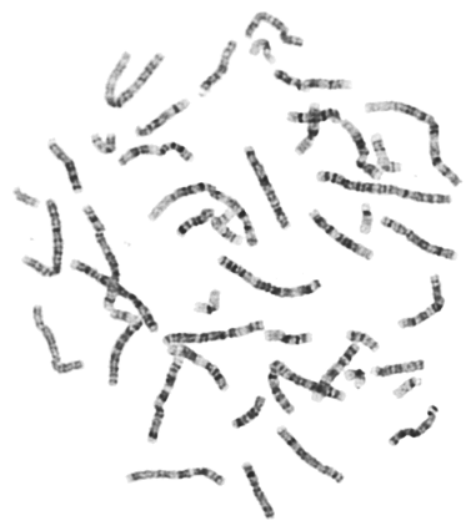

Figure 4. Fetus

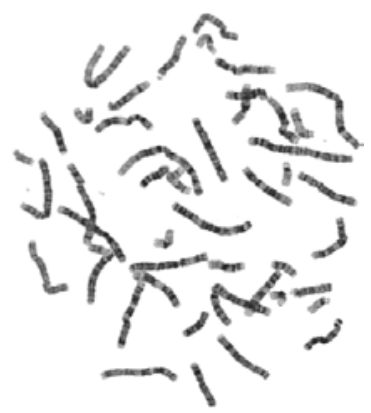

(a)

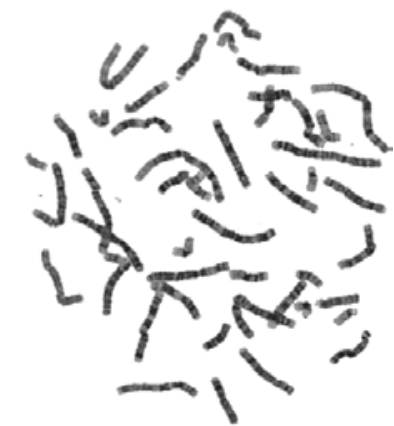

(b)

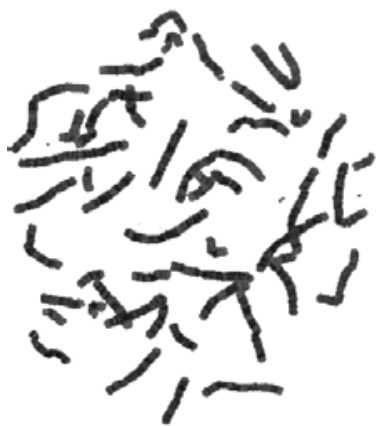

(c)

Figure 5. (a) Fetus Amnion chromosome (MetaSystem), (b) Enhanced image produced by MetaSystem

ves the modification of one or more components of the image to enhance the clarity and details through visual analysis and interpretation [13].

Some researches have been done to provide a robust method for improved the quality of images. The old one is histogram equalization [8]. This method has been optimized to improved enhancement performance, such as contrastlimited adaptive histogram equalization [9]. Besi- de of that, neural network is also used to improve image quality. In [15], autoencoder method is used to enhance image quality based on reconstruction method. The network first strained using some images with noise or blur, and the good images as the target. But the neural network based method needs a lot of data to perform well. Moreover, [16,17] developed methods based on entropy theorem. These previous methods are developed 


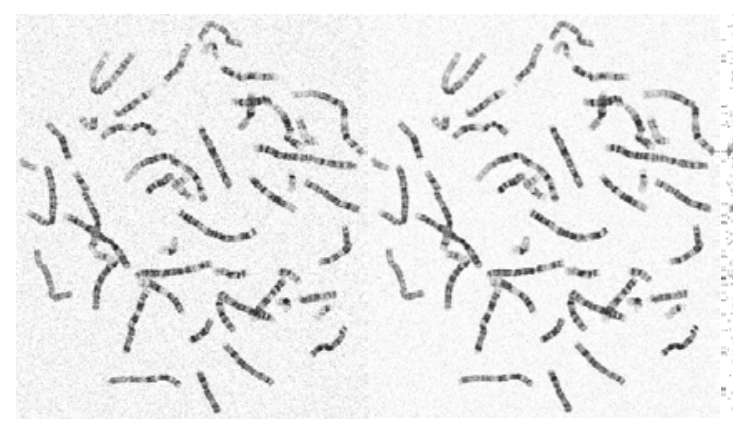

(a)

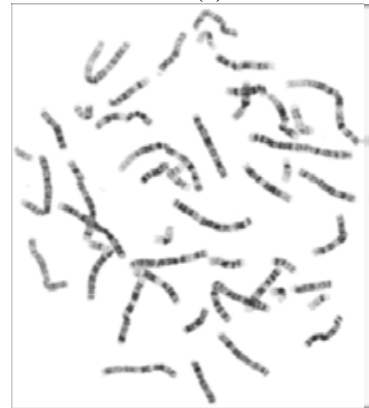

(e) (b)

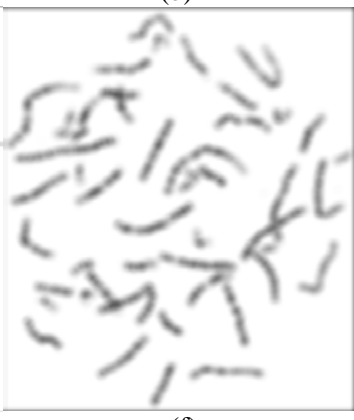

(f)

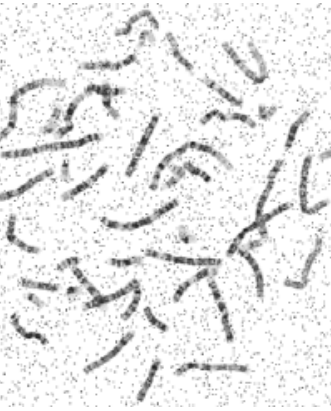

(c)

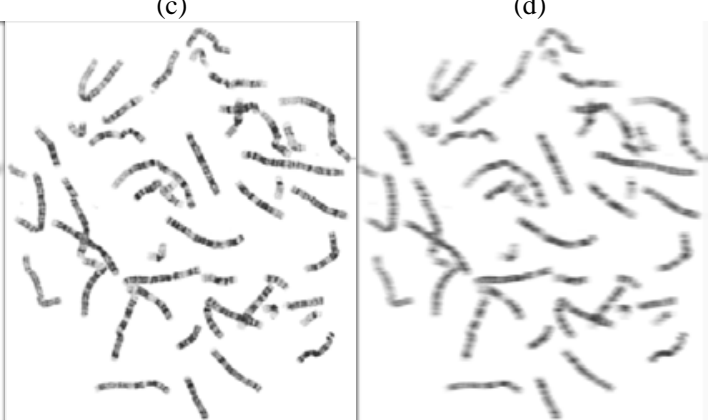

(g)

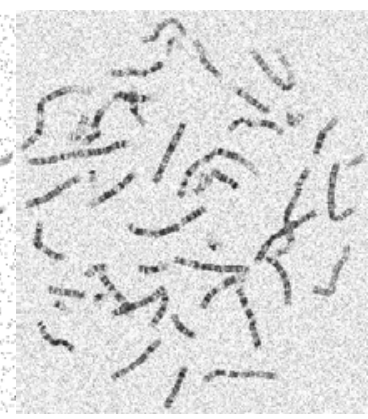

(d)

(h)

Figure 6. (a-d)Noised images (gaussian, poisson, salt \& pepper, speckle), (e-h) Blurred images (average, disk, gaussian, motion)

for natural images. For enhance chromosome image quality, [4-7] have been conducting resarches. [4] proposed multi scale differential operator method. Then, [5-7] used image enhancement methods based on morphological operator. These methods need to set up some parameters manually to achieve the best performance.

\section{Karyotyping Image Processing}

Karyotyping image processing is required to clarify the readings, it is important that there are no errors in the readings in this case there are several steps required so that images can be obtained with good. The process of taking pictures in order to obtain a good image also requires its own skills and should be supported by Microscope, camera and software sufficient [18].

In this case the chromosome image are a chromosome from MetaSystem image demo. MetaSystem is a company engaged in the field of chromosomes image processing software along with hardware and equipment. One of the example for chromosome image is chromosome image from the amniotic fluid. The inspection process of karyotyping performed when the parents of these infants were about to find out whether the baby have congenital defects or not. Pictures of the chromosome can be seen in figure $1 \mathrm{a}$. The process will be done by program which build in Matlab software. Figure 2 is showed how chromosome extracted until the chromosome classify. Then the chromosome is observed under microscope and chromosome photograph. After that, this image enhanced manually using karyotype machine.

\section{Image Enhancement Various Methods}

There are some methods to enhance image quality. They are histogram equalization, contrast-limiting adaptive histogram equalization, gamma adjustment, and histogram equalization with 3D block matching. The methods are described below in detail.

\section{Histogram Equalization (HE)}

Histogram equalization is a technique to adjust the in- tensity of image for a better quality [8]. For an image, I, the histogram of equalized image g can be defined by equation(1):

$$
g_{i, j}=f \operatorname{loor}\left((K-1) \sum_{n=0}^{f_{i, j}} p_{n}\right)
$$

Where $\mathrm{p}_{\mathrm{n}}$ is defined by equation(2):

$$
p_{n}=\frac{\text { pixels number with intensity } n}{\text { total pixels number }} r
$$

Where $n$ has values from 0 to $\mathrm{K}-1 . \mathrm{d}$ 
TABLE 1

EXPERIMENT RESULTS USING FIRST SCENARIO

\begin{tabular}{cclcc}
\multicolumn{4}{c}{ EXPERIMENT RESULTS USING FIRST SCENARIO } \\
\hline No & Images & Method & PSNR & SSIM \\
\hline \multirow{3}{*}{1} & \multirow{3}{*}{ Fig. 5(a) } & Unsharp & 18.5185 & 0.9059 \\
& & HE & 12.0534 & 0.7424 \\
& & CLAHE & $\mathbf{2 4 . 5 8 4 3}$ & 0.9703 \\
& & HE+BM3 & 24.5418 & $\mathbf{0 . 9 6 3 4}$ \\
& & Unsharp & 16.2509 & 0.8636 \\
2 & Fig. 5(b) & HE & 12.0534 & 0.7424 \\
& & CLAHE & $\mathbf{2 1 . 6 7 0 9}$ & $\mathbf{0 . 9 4 5 1}$ \\
& & HE+BM3D & 20.9779 & 0.9317 \\
& & Unsharp & 12.0496 & 0.7441 \\
3 & Fig. 5(c) & HE & 12.0556 & 0.7425 \\
& & CLAHE & $\mathbf{1 7 . 1 3 0 4}$ & $\mathbf{0 . 8 6 8 1}$ \\
& & HE+BM3D & 15.8016 & 0.8359 \\
\hline
\end{tabular}

Unsharp Masking (UM)

Unsharp masking is a method that used for sharpening image quality [11] [19]. The first step is blurring. The blurring process is conducted to original image. Then, the original image is subtracted with the blurred image. After that for the last step is adding some deferences to the original image. Unsharp masking is appropriate to sharpen the images. This technique has two noteworthy downsides, for example, the complexity in the darker region is improved substantially more profound than the lighter zone. The next issue is the technique additionally improves the noise and digitization impacts. Due to these issues, the pictures looses its inventiveness much of the time [11]. Among all image enhancement method, the Unsharp Masking approach is the most effortless and less difficult. Equation(3) is UM formulation.

$$
f(m, n)=g(m, n)+\lambda H g(m, n)
$$

Where, $\mathrm{f}$ is the unsharpened image. $\mathrm{g}$ is the input image, $\mathrm{H}$ is the high pass filter image, and $\lambda$ is gain.

Matlab implement UM in imsharpen function. This function have three parameters Radius, Amount, and Threshold. Radius is the standard deviation of the Gaussian lowpass filter. The Amount is enhance the effect of sharpening and Threshold is the minimum contrast needed for a pixel that is associated with the limit pixels [20]. These three functions influence each other to obtain good sharpness. In the default condition for the Radius value is 1 , Amount is 0.8 and the Threshold is 0 .

Contrast-limiting Adaptive Histogram Equalization (CLAHE)

CLAHE is a method which is developed based on
TABLE 2

\begin{tabular}{|c|c|c|c|c|}
\hline No & Images & Method & PSNR & SSIM \\
\hline \multirow{3}{*}{1} & \multirow{3}{*}{ Fig. 6(a) } & Unsharp & 14.8434 & 0.1786 \\
\hline & & $\mathrm{HE}$ & 6.3547 & 0.0685 \\
\hline & & CLAHE & 13.5149 & 0.1871 \\
\hline \multirow{5}{*}{2} & \multirow{5}{*}{ Fig. 6(b) } & $\mathrm{HE}+\mathrm{BM} 3$ & 27.5375 & 0.9773 \\
\hline & & Unsharp & 14.8434 & 0.1786 \\
\hline & & $\mathrm{HE}$ & 6.3547 & 0.0685 \\
\hline & & CLAHE & 13.5149 & 0.1870 \\
\hline & & $\mathrm{HE}+\mathrm{BM} 3 \mathrm{D}$ & 30.6567 & 0.9846 \\
\hline \multirow{3}{*}{3} & \multirow{3}{*}{ Fig. 6(c) } & Unsharp & 14.8434 & 0.1786 \\
\hline & & $\mathrm{HE}$ & 6.3547 & 0.0685 \\
\hline & & CLAHE & 13.5149 & 0.1870 \\
\hline \multirow{5}{*}{4} & \multirow{5}{*}{ Fig. 6(d) } & $\mathrm{HE}+\mathrm{BM} 3 \mathrm{D}$ & 18.2848 & 0.4071 \\
\hline & & Unsharp & 14.8434 & 0.1786 \\
\hline & & $\mathrm{HE}$ & 6.3547 & 0.0685 \\
\hline & & CLAHE & 13.5149 & 0.1870 \\
\hline & & $\mathrm{HE}+\mathrm{BM} 3 \mathrm{D}$ & 20.6997 & 0.7049 \\
\hline
\end{tabular}

TABLE 3

EXPERIMENT RESULTS USING THE THIRD SCENARIO

\begin{tabular}{cclcc}
\hline No & Images & Method & PSNR & SSIM \\
\hline \multirow{3}{*}{1} & \multirow{3}{*}{ Fig. 6(e) } & Unsharp & 22.3642 & $\mathbf{0 . 9 3 0 1}$ \\
& & HE & 9.9749 & 0.6012 \\
& & CLAHE & 25.2435 & 0.9238 \\
& & HE+BM3 & $\mathbf{2 6 . 6 1 8 9}$ & 0.9235 \\
2 & \multirow{4}{*}{ Fig. 6(f) } & HE & 7.4021 & 0.4638 \\
& & CLAHE & 17.5649 & 0.7344 \\
& & HE+BM3D & $\mathbf{2 0 . 5 5 4 2}$ & 0.7883 \\
& & Unsharp & 23.3867 & 0.9249 \\
3 & Fig. 6(g) & HE & 10.3996 & 0.6232 \\
& & CLAHE & 29.9063 & $\mathbf{0 . 9 5 9 8}$ \\
& & HE+BM3D & $\mathbf{3 2 . 3 4 8 1}$ & 0.9594 \\
& & Unsharp & 21.3768 & 0.8736 \\
4 & Fig. 6(h) & HE & 8.8323 & 0.5711 \\
& & CLAHE & 20.7138 & 0.8492 \\
& & HE+BM3D & $\mathbf{2 2 . 9 0 8 9}$ & $\mathbf{0 . 8 7 5 9}$ \\
\hline
\end{tabular}

adaptive histogram equalization (AHE) [9]. In AHE, the intensity of the pixel is transformed into the display range proportional to the pixel intensity's rank in the local intensity histogram. In some cases, AHE can be over-enhancement the noise and may reduce the effect of edgeshadowing. To prevent this event, CLAHE uses strategy to enhance image quality by reduced for very uniform image areas. The calculation is a refinement method which is modified using miposing a user-specified maximum of the local histogram height, and thus on maximum factor of contrast enhancement. 
Histogram Equalization with 3D Block Matching $(H E+B M 3 D)$

$\mathrm{BM} 3 \mathrm{D}$ is an algorithm for noise removal which is proposed by [10]. This method utilizes Wiener filter as a collaborative form. The filter is used to filter dimensional patches block by clustering similar blocks from 2D to 3D array of data and afterward denoising the gathered fixes mutually. Then, the denoised patches are connected back to the first pictures by a voting instrument which expels noise from the considered area.

In general, this method consists of two steps, basic estimate step and final estimate step. These two steps have similar method to produce output. The differences are on the input and grouping phase. Basic estimate step uses a noisy image as the input. Then the input is grouped by block matching. In final estimate step, there are two inputs, the noisy image and the estimate image which is basic estimate step result. On the grouping phase, final estimate step will produce two groups (3-D arrays). They come from basic estimate step result and the noisy image.

$$
\begin{aligned}
& d\left(Z_{X R}, Z_{X}\right) \\
& =\frac{\left\|Y^{\prime}\left(T_{2 D}^{H T}\left(Z_{X R}\right)\right)-Y^{\prime}\left(T_{2 D}^{H T}\left(Z_{X}\right)\right)\right\|_{2}^{2}}{\left(N_{1}^{h t}\right)^{2}}
\end{aligned}
$$

\section{Experiment Setup}

In this section, we were described about data which we used in the experiment, scenarios of experiments, and performance measurement methods.

Data

To conduct experiments, we used chromosome image which is produced after karyotyping process. We did two transformations before the image ready to enhance. First, we removed the background image by converted into a white color. As figure 1a shows that the background region has gray color. The gray pixels are spun above 225 as shown in figure 3. Then, the intensity of pixels above 225 are converted into 255, so the background changes into white color. Figure 1b was the result of background removing step.

\section{Scenarios of Experiments}

We arranged our experiments into three scenarios. In the first scenario, the image that is enhanced by a meta system are embezzled. This process is conducted manually using Photoshop Software. We made three different dark images which have a different dark level. Moreover, the second scenario is enhanced image which has added some noises. There are several noise types we used.
They are Gaussian noise, poison noise, salt and pepper noise, and speckle noise. The last scenario is enhanced blurred image. We made 4 images. Each image was filtered using different filter. We chose an average filter, disk filter, Gaussian filter, and motion filter. They are built in Matlab. Some filters (log, Sobel, Prewitt) are not used because those filters used to detect object edges.

\section{Performance Measurement Methods}

To measure the methods, we used two measure0ment methods, peak signal-to-noise ratio and structural similarity index. These methods are described below.

Peak Signal-to-Noise Ratio (PSNR). PSNR is an image comparison method which is usually used to measure reconstruction quality for lossy compression. [21] showed that PSNR is a valid method to measure image quality. On the other hand, PSNR also has low complexity. It makes the implementation easier. As an example of PSNR method with image I, which have mxn and free of noise, the mean square error (MSE) of I and reconstructed version $\mathrm{L}$ is expressed by equation(5):

$$
M S E=\frac{1}{m n} \sum_{i=0}^{m-1} \sum_{j=0}^{n-1}[(I(i, j)-L(i, j))]^{2}
$$

Then, the PSNR in decibels $(\mathrm{dB})$ is defined by equation(6):

$$
P S N R=10 \log _{10}\left\{\frac{\max (I)^{2}}{M S E}\right\}
$$

Structural Similarity Index (SSIM). SSIM is used to capture the sense digital images and video quality. SSIM is formed as a metric which may perceive digital images and video quality [22] [23]. It is used to get the similarity on two images. PSNR and MSE are known as methods which quantify absolute error for the reference and result image. A measurement method like PSNR and MSE may not measure a complete similarity. To give a good measurement, SSIM tries to quantify the change in structure of the image. SSIM can be expressed by equation(7):

$$
\begin{aligned}
& \operatorname{SSIM}(x, y) \\
& =\frac{\left(2 \mu_{x} \mu_{y}+c_{1}\right)\left(2 \sigma_{x y}+c_{2}\right)}{\left(\mu_{x}^{2}+\mu_{y}^{2}+c_{1}\right)\left(\sigma_{x}^{2}+\sigma_{y}^{2}+c_{2}\right)}
\end{aligned}
$$

\section{Results and Analysis}


In this section, we described the results of the experiments based on experiment scenarios. First, we described experiment results from using dark images. After that, results by using noise images as input images. Then, the results of experiments using the third scenario.

Table 1 shows the result of experiments which is conducted using the first scenario. As described above, we used 3 chromosome images (figure 5). CLAHE shows that has higher PSNR for the three images. Beside of that, HE+BM3D has PSNR value not far enough from CLAHE. The SSIM measurement also shows that these two methods performed well.

The next experiment is using the second scenario. Based on the result of a experiment, HE+BM3D method out performed the other method. This result is not surprising that HE+BM3D outperformed the other methods for 4 types of noise images. It is caused because the other method tried to enhance the intensity without noise removing process.

Table 3 showed the result for the third scenario. It shows that on PSNR measurement, $\mathrm{HE}+\mathrm{BM} 3 \mathrm{D}$ give the highest value for every image. Different results are shown on the SSIM measurement. HE+BM3D did not give the highest value, but it is always on the two highest SSIM value.

\section{Conclusion}

In this study, some methods, which is developed to enhance image quality, are compared. These methods are used to enhance the image that resulted by karyotyping process. This process is a part of preprocessing in classifying chromosome. By the experiments and analysis, $\mathrm{HE}+\mathrm{BM} 3 \mathrm{D}$ gave stable results for the three scenarios, event hough, in the first and third scenario didn't give the highest PSNR and SSIM values. It is also shown that $\mathrm{HE}+\mathrm{BM} 3 \mathrm{D}$ can adapt on dark image, noised image, and blurred image.

\section{References}

[1] A. Lima-de Faria, Praise of Chromosome" folly": Confessions of an Untamed Molecular Structure. World Scientific, 2008.

[2] J. S. Hwang, “Topic 2a: Chromosome,” class notes for Human Molec- ular Genetics, USCSI University, Kuala Lumpur, Malaysia, 2013.

[3] A. Khmelinskii, R. Ventura, and J. Sanches, "Chromosome pairing for karyotyping purposes using mutual information,” in 2008 5th IEEE International Symposium on
Biomedical Imaging: From Nano to Macro, May 2008, pp. 484-487.

[4] Y.-P. Wang, Q. Wu, K. R. Castleman, and Z. Xiong, "Chromosome image enhancement using multiscale differential operators,” IEEE Transactions on Medical Imaging, vol. 22, no. 5, pp. 685-693, 2003.

[5] W. Yan, "Mathematical morphology based enhancement for chromo- some images," in Bioinformatics and Biomedical Engineering, 2009. ICBBE 2009. 3rd International Conference on. IEEE, 2009, pp. 1-3.

[6] P. Wayalun, P. Chomphuwiset, N. Laopracha, and P. Wanchanthuek, "Images enhancement of g-band chromosome using histogram equal- ization, otsu thresholding, morphological dilation and flood fill techniques," in Computing and Networking Technology (ICCNT), 2012 8th International Conference on. IEEE, 2012, pp. 163-168.

[7] W. Yan, "Enhancement methods for chromosome images," in Electri- cal and Control Engineering (ICECE), 2011 International Conference on. IEEE, 2011, pp. 3024-3026.

[8] Y.-T. Kim, "Contrast enhancement using brightness preserving bi- histogram equalization," IEEE transactions on Consumer Electronics, vol. 43, no. 1, pp. 1-8, 1997.

[9] K. Zuiderveld, “Contrast limited adaptive histogram equalization,” in Graphics gems IV. Academic Press Professional, Inc., 1994, pp. 474-485.

[10]K. Dabov, A. Foi, V. Katkovnik, and K. Egiazarian, "Image denoising by sparse 3-d transform-domain collaborative filtering," IEEE Trans- actions on image processing, vol. 16, no. 8, pp. 2080-2095, 2007.

[11] T. Luft, C. Colditz, and O. Deussen, Image enhancement by unsharp masking the depth buffer. ACM, 2006, vol. 25, no. 3.

[12] J. S. Hwang, “Topic 2b: Chromosomal mutation,” class notes for Human Molecular Genetics, USCSI University, Kuala Lumpur, Malaysia, 2013.

[13]M. S. Alkoffash, M. J. Bawaneh, H. Muaidi, S. Alqrainy, and M. Alzghool, “A survey of digital image processing techniques in character recognition,” International Journal of Computer Science and Network Security (IJCSNS), vol. 14, no. 3, p. 65, 2014.

[14]R. Kusumanto and A. N. Tompunu, "Pengolahan citra digital untuk mendeteksi obyek menggunakan pengolahan warna model normal- isasi rgb," Semantik, vol. 1, no. 1, 2011. 
58 Jurnal Ilmu Komputer dan Informasi (Journal of Computer Science and Information), Volume 10, Issue 1, June 2017

[15]K. G. Lore, A. Akintayo, and S. Sarkar, "Llnet: A deep autoencoder approach to natural low-light image enhancement,” arXiv preprint arXiv:1511.03995, 2015.

[16] Y. Niu, X. Wu, and G. Shi, “Image enhancement by entropy max- imization and quantization resolution upconversion," in 2014 IEEE International Conference on Image Processing (ICIP). IEEE, 2014, pp. 4047-4051.

[17] C. Li, Y. Yang, L. Xiao, Y. Li, Y. Zhou, and J. Zhao, "A novel image enhancement method using fuzzy sure entropy,” Neurocomputing, vol. 215, pp. 196-211, 2016.

[18]H. Kapitza and S. Lichtenberg, Microscopy from the very beginning. Zeiss, 1997.

[19] J. N. Archana and P. Aiswarya, “A review on the image sharpening algorthms using unsharp masking," International Journal of Engi- neering Science and Computing, vol. 6, no. 7, 2016.
[20] R. C. Gonzalez, R. E. Woods, and S. L. Eddins, Digital Image Processing Using MATLAB. Upper Saddle River, NJ, USA: Prentice- Hall, Inc., 2003.

[21] Q. Huynh-Thu and M. Ghanbari, "Scope of validity of psnr in image/video quality assessment," Electronics Letters, vol. 44, no. 13, pp. 800-801, June 2008.

[22] A. Łoza, D. R. Bull, P. R. Hill, and A. M. Achim, "Automatic contrast enhancement of low-light images based on local statistics of wavelet coefficients," Digital Signal Processing, vol. 23, no. 6, pp. 1856-1866, 2013.

[23] Z. Wang, A. C. Bovik, H. R. Sheikh, and E. P. Simoncelli, "Image quality assessment: from error visibility to structural similarity,” IEEE transactions on image processing, vol. 13, no. 4, pp. 600-612, 2004. 